\title{
Forensic Study for Genetic Sex Determination of Burnt Powdered Skeletal Fragments from Sokoto, Northwestern Nigeria.
}

\author{
*Zagga $\mathrm{AD}^{1}$, Ismail $\mathrm{SM}^{2}$, Ahmed $\mathrm{H}, \mathrm{OON}^{3}$ and Tadros $\mathrm{AA}^{1}$. \\ ${ }^{I}$ Department of Anatomy, College of Health Sciences, Usmanu Danfodiyo University, Sokoto, Sokoto State, \\ Nigeria. \\ ${ }^{2}$ Department of Medical Molecular Genetics, Division of Human Genetics and Genome Research, National \\ Research Centre, Cairo, Egypt. \\ ${ }^{3}$ Department of Paediatrics, College of Health Sciences, Usmanu Danfodiyo University, Sokoto, Sokoto State, \\ Nigeria.
}

\begin{abstract}
Sex determination is not only a useful tool but of extreme necessity in forensic investigations specifically in cases of sexual assault, aged blood stains and human skeletal remains whereby rapid, sensitive, accurate and reliable methods of investigation are of the utmost importance. A forensic study for genetic sex determination of burnt powdered skeletal fragments from Sokoto, Northwestern Nigeria, using amelogenin gene and alphoid repeats primers was undertaken. With amelogenin gene primers, a success rate of $33.3 \%$ was recorded for correct genetic sex identification. PCR Sensitivity $=100 \%$, Specificity $=25 \%$, Predictive value of positive test $=40 \%$, Predictive value of negative test $=100 \%$, False positive rate $=300 \%$, False negative

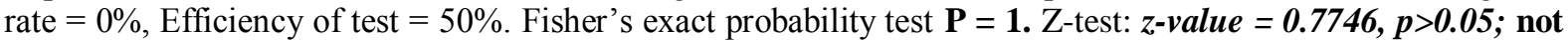
statistically significant. Alphoid repeats primers, yielded a success rate of $50 \%$ for correct genetic sex identification. PCR Sensitivity $=100 \%$, Specificity $=33 \%$, Predictive value of positive test $=60 \%$, Predictive value of negative test $=100 \%$, False positive rate $=200 \%$, False negative rate $=0 \%$, Efficiency of test $=83 \%$.

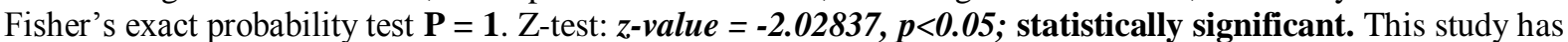
demonstrated the use of amelogenin gene and alphoid repeats in forensic study for genetic sex determination of burnt powdered skeletal fragments from Sokoto, Northwestern Nigeria, and that alphoid repeats yielded better results than amelogenin gene. This is the first known study determining the sex of burnt cadaveric skeletal fragments by means of PCR in Nigeria. There is need for further studies in Nigeria to complement the findings of this study.
\end{abstract}

Key Words: Bone, Fire, Identification, Sex, Sokoto.

\section{Introduction}

Substantial effort has continuously been made in an attempt to identify cadavers and human remains after wars, socio-political problems and mass disasters [1]. In addition, because of the social dynamics of large cities, there are always cases of missing people, as well as unidentified cadavers and human remains that are found. There has also been an increase in requests for exhumation of human remains in order to determine genetic relationships in civil suits and court action [2].

While the establishment of identity from intact fresh corpses is often obvious, the correct determination of sex may be difficult after catastrophic events such as fires, high impact crashes and explosions and in criminal cases where decomposed bodies are found [3]. Problems of sex identification arise in cases where skeletal remains are fragmentary or are those of juveniles or infants [4].

The identity of a deceased person is a vital factor in facilitating investigations and assisting in legal disputes, inquests and other tribunals [5]. Identification of remains is dependent on broad classifications of age, race and sex. Some burial practices and post depositional conditions which are common to many archaeological sites (e.g. Low $\mathrm{pH}$ ) result in very little and/or poorly preserved bone thus rendering identification of sex difficult if not impossible [6].

Burning of corpses is a well known and widely spread funeral procedure that has been performed for a long time in many cultures. Nowadays more and more corpses are burned in cremations and buried in urns, often for practical and financial reasons. In some scientific, criminal or civil cases even after cremation, there is the need of genetic investigations for identification or paternity testing [7].

From a forensic perspective, fire is arguably one of the most destructive forces in our society [8]. A physical fire can result in soft tissue damage so extensive that conventional methods of identification are precluded. Because of the durability of the mineralized bone and dental structures and the protection afforded by the soft tissues for the bones and hard tissue mass of the head, bones and teeth resist postmortem degradation and can withstand extreme environmental insult [9] and incineration [10, 11]. Usually cremation takes place as temperatures of over $1000^{\circ} \mathrm{C}$ for more than 70 minutes, destroying the corpse and only leaving severely burned 
teeth and some fragments of larger bones [7]. Even in severe conflagrations, such as vehicle fires, explosions, and aircraft crashes, preservation of the bone and dentition is common and often used as a primary or contributory method of identification $[12,13]$.

The general objective of this study was therefore, to undertake a forensic study for genetic sex determination of burnt powdered skeletal fragments from Sokoto, Northwestern Nigeria, using amelogenin gene and alphoid repeats primers.

\section{Materials And Methods}

A total of six cadaveric fragments of bones obtained from the remains of dissected cadavers in the Department of Anatomy, College of Health Sciences, Usmanu Danfodiyo University, Sokoto, Nigeria were exposed to various degrees of temperatures for 20 minutes each, after pulverization. Each pulverized cadaveric skeletal fragment measured about $0.5 \mathrm{~cm} \times 0.5 \mathrm{~cm}$. The cadaveric skeletal fragments comprised of: (1) Little Finger (2) Hip bone (3) Femur (4) Rib (5) Scapula (6) Fibula. The laboratory experiment was carried out at the Department of Medical Molecular Genetics, Division of Human Genetics and Genome Research, National Research Centre, Cairo, Egypt.

The protocol for precaution against contamination was based on the method employed by Cooper and Poinar, (2000) [14], with minimal modification. While Cooper and Poinar, (2000) [14] used separate rooms for DNA extraction and PCR amplification, we used same room for these but under two different hoods. Specific and stringent precautions were undertaken to handle specimen during DNA extraction and amplification. Specimen were handled (using disposable masks, gloves and laboratory coats) in an area where no other DNA studies were simultaneously carried out. The DNA extraction and the setting up of PCR reactions of DNA templates were carried out under two different hoods, daily irradiated with UV rays $(254 \mathrm{~nm})$. Only disposable sterile tubes, filtered tips, sterile reagents and solutions, exclusively dedicated for DNA studies, were used. A set of pipettes, once used was not used again for DNA extraction, PCR amplification and analysis of the PCR products (Cooper and Poinar, 2000) [14].

The equipment and surface of the hood were cleaned with distilled water, sterilised with $70 \%$ ethanol and UV irradiated before and after grinding each sample. A sheet of aluminium foil sterilised with $70 \%$ ethanol was placed on the surface of the hood. Samples were further sterilised with $70 \%$ ethanol and a sterile soft tissue was used to absorb excess ethanol from the sample (to dry the sample and minimise the PCR inhibitory effect of alcohol) before grinding. Each sample (one sample at a time) was then placed in a sterile mortar and pestle, for pulverisation. Pulverisation continued until the tooth turned into powder form. Aliquot of the ground tooth powder was then transferred into $1.5 \mathrm{ml}$ microtubes and stored in a refrigerator at $-80^{\circ} \mathrm{C}$, before DNA extraction.

The experimental conditions for furnace incineration of the ground bone powders were based on Rees and Cox (2010) [15], with only one minor modification. While Rees and Cox (2010) [15], heated their samples up to only 15 minutes, we decided to increase this to 20 minutes to ensure proper incineration: First, the ground bone powder was transferred into crucible. The mouth of the crucible was covered with a sheet of aluminium foil. Bone powders were heated in a type 201 chamber furnace (Carbolite, Hope Valley, U.K.) at temperatures of $100^{\circ} \mathrm{C}, 150^{\circ} \mathrm{C}, 200^{\circ} \mathrm{C}, 250^{\circ} \mathrm{C}$, and $300^{\circ} \mathrm{C}$, respectively. One sample was heated into ashes (no temperature regulation required). The chamber furnace was preheated to the designated temperature prior to sample heating. Samples were placed separately in crucibles and heated for 20 minutes.

The burnt samples were allowed to cool before being transferred into a $1.5 \mathrm{ml}$ microtube for DNA extraction, by standard phenol-chloroform method, according to Capelleni et al., 2004 [16]. The samples consisted of about $0.3 \mathrm{mg}$ aliquot of the ground bone powder.

PCR amplification of the extracted DNA for sex determination used previously prescribed amelogenin gene multiplex primers by Faerman et al., 1995 [4] and Matheson and Loy, 2001 [17] and alphoid repeats primers by Witt and Erickson, 1989 [18]. For PCR amplification with amelogenin gene primers a master mix was prepared in a single $0.5 \mathrm{ml}$ PCR tube from: $2.5 \mu \mathrm{l}$ of $10 \mathrm{x}$ Buffer, $2.5 \mu \mathrm{l}$ of dNTPs, $2.5 \mu \mathrm{l}$ of $\mathrm{MgCl}_{2}, 4 \mu \mathrm{l}$ of forward primer M4, $2 \mu \mathrm{l}$ of X reverse primer M5 and $2 \mu \mathrm{l}$ of Y reverse primer M6, $1.25 \mu \mathrm{l}$ of Taq polymerase and $6.25 \mu \mathrm{l}$ of DEPC water. A total volume of $23 \mu \mathrm{l}$ from the master mix was transferred into six $0.25 \mathrm{ml}$ microtubes. $1 \mu \mathrm{l}$ Paraffin oil was added to seal and avoid evaporation of the reaction mixture. $2 \mu \mathrm{l}$ DNA (template) from the respective 6 samples was finally added to accomplish a reaction volume of $25 \mu \mathrm{l}$ for each tube. Normal PCR was accomplished in a thermocycler (Minicycler ${ }^{\mathrm{TM}}$ MJ RESARCH), in a $25 \mu 1$ reaction volume, to amplify selected sequences of the amelogenin gene, as follows; Denaturation step: was at $94^{\circ} \mathrm{C}$ for 1 minute. Annealing step: was at $55^{\circ} \mathrm{C}$ for 2 minutes. Extension/elongation step: was at $72^{\circ} \mathrm{C}$ for 2 minutes. The above first three steps were repeated for 40 cycles. Final extension/elongation: was at $72^{\circ} \mathrm{C}$ for 15 minutes. Cooling of the reaction process: was at $4{ }^{\circ} \mathrm{C}$ for 48 hours.

Amplification with alphoid repeats primers was prepared separately each for $\mathrm{X}$ (X1 and $\mathrm{X} 2$ ) primers, and Y (Y11 and Y22) primers, respectively, in two separate $0.5 \mathrm{ml} \mathrm{PCR} \mathrm{tubes.} \mathrm{The} \mathrm{master} \mathrm{mix} \mathrm{for} \mathrm{each} \mathrm{of} \mathrm{X}$ and Y chromosomes was separately constituted from: $2.5 \mu \mathrm{l}$ of 10x buffer, $2.5 \mu \mathrm{l}$ of dNTPs, $2.5 \mu \mathrm{l}$ of forward primer 
for $\mathrm{X}=\mathrm{X} 1,2.5 \mu \mathrm{l}$ of reverse primer for $\mathrm{X}=\mathrm{X} 2,2.5 \mu \mathrm{l}$ of forward primer for $\mathrm{Y}=\mathrm{Y} 11,2.5 \mu 1$ of reverse primer for $\mathrm{Y}=\mathrm{Y} 22,0.5 \mu \mathrm{l}$ of Taq DNA polymerase and 17.5 $\mu \mathrm{l}$ of DEPC water. A total volume of $33 \mu \mathrm{l}$ from the master mix was transferred into six $0.25 \mu$ l tubes, for $\mathrm{X}$ and $\mathrm{Y}$, respectively and $1 \mu \mathrm{l}$ Paraffin oil added to seal and avoid evaporation of the reaction mixture. A volume of $2 \mu \mathrm{l}$ DNA from the respective 6 samples was finally added to the 6 tubes (containing PCR reagents for X and Y respectively), to accomplish a reaction volume of 35 $\mu \mathrm{l}$ for each tube. Normal PCR was accomplished in a thermocycler (Minicycler ${ }^{\mathrm{TM}}$ MJ RESARCH) in a $35 \mu \mathrm{l}$ reaction volume, to amplify selected sequences of the alphoid repeats, as follows; Initialization step at $95^{\circ} \mathrm{C}$ for 5 minutes. Denaturation step at $94^{\circ} \mathrm{C}$ for 40 seconds. Annealing step at $55^{\circ} \mathrm{C}$ for 40 seconds. Extension/elongation step at $72^{\circ} \mathrm{C}$ for 40 seconds. Steps 2-4 were repeated for 35 cycles. Final extension/elongation step at $72^{\circ} \mathrm{C}$ for 40 seconds. Cooling of reaction process at $4^{\circ} \mathrm{C}$ for 48 hours.

The protocol employed by Maniatis, et al., (1982) [19] for preparation of Agarose gel electrophoresis was adopted. Amplification with amelogenin primers was at 330 base pair (bp) bands for X chromosome, and 218 base pair (bp) bands for Y chromosome, respectively. With alphoid repeats primers, X-specific primer amplified at 130 base pair (bp) bands and Y-specific primer amplified at 170 base pair (bp) bands respectively.

The expected amplification products of amelogenin gene and alphoid repeats sequences were visualised by electrophoresis in 1.5\% agarose gel containing $4 \mu \mathrm{l}$ ethidium bromide. For both amelogenin gene and alphoid repeats, a molecular weight marker was always included in the first lanes (Fig. 1 for amelogenin gene, figs. $2 \mathrm{a}$ and $2 \mathrm{~b}$ for alphoid repeats). Fisher's exact test (probability) and Z-test were employed for comparison of values. The sensitivity, specificity, efficiency, predictive value of positive tests, predictive value of negative tests, false positive rates and false negative rates of the PCR were determined according to the arithmetic definitions of these terms.

\section{Results}

Table 1 shows the details of the genetic sex identification of bone samples, with amelogenin gene, after being exposed to various degrees of temperature for 20 minutes. Amplification for Y chromosome was achieved in all the samples, except in sample 6, which showed negative. Amplification for X chromosome was achieved in samples 1 and 2 only. Accurate genetic sex identification was achieved in samples 2 and 3 only. Genetic sex of samples 1, 4 and 5 were wrongly identified as males, instead of females. No genetic sex identification was achieved for sample burnt to ashes (sample 6).

Table 1: Results of Genetic Sex Identification of Bone Samples Exposed to Various Degrees of Temperature Using Amelogenin gene Primers.

\begin{tabular}{|c|c|c|c|c|c|c|}
\hline \multirow[t]{2}{*}{$\begin{array}{l}\text { Serial } \\
\text { number }\end{array}$} & \multirow{2}{*}{$\begin{array}{l}\text { Degrees to } \\
\text { which } \\
\text { bone was } \\
\text { heated }\end{array}$} & \multirow[t]{2}{*}{$\begin{array}{l}\text { Bone } \\
\text { sampled }\end{array}$} & \multirow[t]{2}{*}{$\begin{array}{l}\text { Morphological } \\
\text { Sex }\end{array}$} & \multicolumn{2}{|c|}{$\begin{array}{l}\text { PCR results with amelogenin gene } \\
\text { primers }\end{array}$} & \multirow[t]{2}{*}{ Genetic sex } \\
\hline & & & & $\begin{array}{l}\mathrm{X} \text { chromosome } \\
\text { amplification } \\
(330 \mathrm{bp})\end{array}$ & $\begin{array}{l}\text { Y chromosome } \\
\text { amplification } \\
(218 \mathrm{bp}\end{array}$ & \\
\hline 1 & $100^{\circ} \mathrm{C}$ & $\begin{array}{l}\text { Little } \\
\text { finger }\end{array}$ & Female & Positive & Positive & Male \\
\hline 2 & $150^{\circ} \mathrm{C}$ & Hip bone & Male & Positive & Positive & Male \\
\hline 3 & $200^{\circ} \mathrm{C}$ & Femur & Male & Negative & Positive & Male \\
\hline 4 & $250^{\circ} \mathrm{C}$ & Rib & Female & Negative & Positive & Male \\
\hline 5 & $300^{\circ} \mathrm{C}$ & Scapula & Female & Negative & Positive & Male \\
\hline 6 & Ashes & Fibula & Female & Negative & Negative & Unidentified \\
\hline
\end{tabular}

Accurate genetic sex identification was achieved in samples 2 and 3 only (both were males). Genetic sexes of samples 1, 4 and 5 were wrongly identified as males, instead of females. No genetic sex identification was achieved for sample burnt to ashes (see Table 1 and Fig. 1). PCR Sensitivity $=100 \%$, Specificity $=25 \%$, Predictive value of positive test $=40 \%$, Predictive value of negative test $=100 \%$, False positive rate $=300 \%$, False negative rate $=0 \%$, Efficiency of test $=50 \%$. Fisher's exact probability test $\mathbf{P}=1$. Z-test: $z$-value $=$ $0.7746, p>0.05$; not statistically significant.

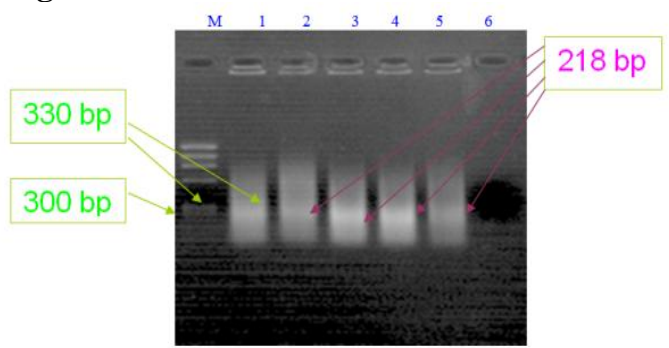

Figure 1: Amplification of the amelogenin gene $\mathrm{X}$ and $\mathrm{Y}$ primers from the DNA of the bone samples exposed to various degrees of heat for 20 minutes, electrophoretically separated on 1.5\% agarose gel (Reassay: 005/14). 
Lanes: $\mathrm{M}=1000$ bp DNA ladder (Lot: 73020G3. Toyobo); $1=$ Little finger exposed to $100^{\circ} \mathrm{C} ; 2=$ Hip bone exposed to $150^{\circ} \mathrm{C} ; 3=$ Femur exposed to $200^{\circ} \mathrm{C} ; 4=$ Rib exposed to $250^{\circ} \mathrm{C} ; 5=$ Scapula exposed to $300^{\circ} \mathrm{C} ; 6=$ Fibula burnt to ashes.

Table 2 presents the details of the PCR sex determination of human bone fragments exposed to various degrees of temperatures for 20 minutes, with alphoid repeats primers. Amplification was achieved for X chromosome in all the samples, except sample 6 (negative). Amplification for $\mathrm{Y}$ chromosome was achieved in samples 1 and 2 only. PCR reaction for Y chromosome was not done for samples 3-6. Correct genetic sex identification was achieved in samples 2, 4 and 5. Thus, sample 2 was accurately identified as male, while samples 4 and 5 were correctly identified as females, genetically. Genetic sexes of samples 1 and 3 were wrongly identified. Sample 1 was wrongly identified as a male, instead of a female, while sample 3 was wrongly identified as a female, instead of a male. No genetic sex identification was achieved for sample 6 (both X and Y chromosomes were negative).

Table 2: Results of Genetic Sex Identification of Bone Samples Exposed to Various Degrees of Temperature, Using Alphoid Repeats Primers.

\begin{tabular}{|c|c|c|c|c|c|c|}
\hline \multirow[t]{2}{*}{$\begin{array}{l}\text { Serial } \\
\text { number }\end{array}$} & \multirow{2}{*}{$\begin{array}{l}\text { Degrees to } \\
\text { which bone } \\
\text { was heated }\end{array}$} & \multirow[t]{2}{*}{ Bone sampled } & \multirow[t]{2}{*}{$\begin{array}{l}\text { Morpho- } \\
\text { logical sex }\end{array}$} & \multicolumn{2}{|c|}{$\begin{array}{l}\text { PCR results with alphoid repeats } \\
\text { primer }\end{array}$} & \multirow[t]{2}{*}{ Genetic sex } \\
\hline & & & & $\begin{array}{l}X \text { chromosome } \\
\text { amplification } \\
(130 \mathrm{bp})\end{array}$ & $\begin{array}{l}\text { Y chromosome } \\
\text { amplification } \\
(170 \mathrm{bp})\end{array}$ & \\
\hline 1 & $100^{\circ} \mathrm{C}$ & Little Finger & Female & Positive & Positive & Male \\
\hline 2 & $150^{\circ} \mathrm{C}$ & Hip bone & Male & Positive & Positive & Male \\
\hline 3 & $200^{\circ} \mathrm{C}$ & Femur & Male & Positive & Not done & Female \\
\hline 4 & $250^{\circ} \mathrm{C}$ & Rib & Female & Positive & Not done & Female \\
\hline 5 & $300^{\circ} \mathrm{C}$ & Scapula & Female & Positive & Not done & Female \\
\hline 6 & Ashes & Fibula & Female & Negative & Not done & Unidentified \\
\hline
\end{tabular}

Correct genetic sex identification was achieved in samples 2, 4 and 5. Genetic sexes of samples 1 and 3 were wrongly identified. Sample 1 was wrongly identified as a male, instead of a female, while sample 3 was wrongly identified as a female instead of a male. PCR reaction for Y chromosome was not done for samples 3-6. No genetic sex identification was achieved for sample 6 (both X and Y chromosomes were negative; see Table 2, Figs. 2a and 2b). PCR Sensitivity $=100 \%$, Specificity $=33 \%$, Predictive value of positive test $=60 \%$, Predictive value of negative test $=100 \%$, False positive rate $=200 \%$, False negative rate $=0 \%$, Efficiency of

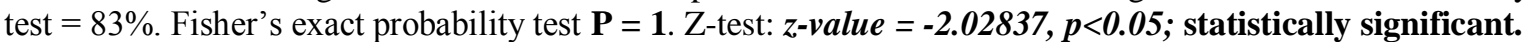

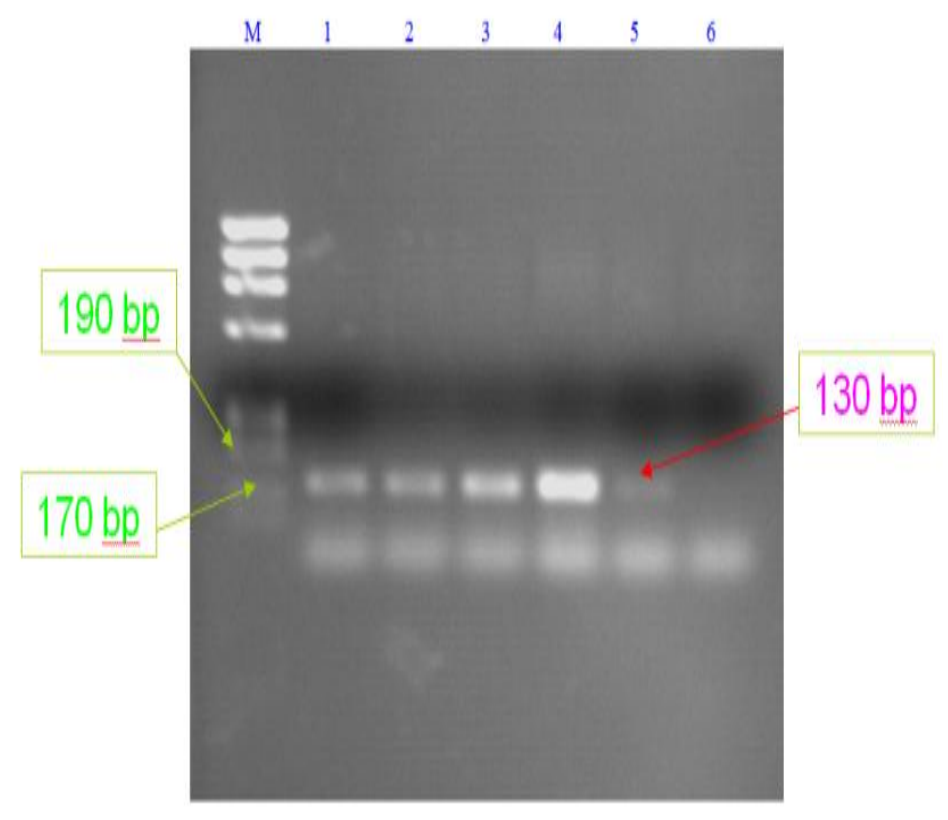

Figure 2a: Amplification of the alphoid repeats X-specific primers from the DNA of the bone samples exposed to various degrees of heat for 20 minutes, electrophoretically separated on 1.5\% agarose gel (Reassay: 005/14).

Lanes: $\mathrm{M}=1000$ bp DNA ladder (Lot: $73020 \mathrm{G} 3$. Toyobo); $1=$ Little finger exposed to $100^{\circ} \mathrm{C} ; 2=$ Hip bone exposed to $150^{\circ} \mathrm{C} ; 3=$ Femur exposed to $200^{\circ} \mathrm{C} ; 4=$ Rib exposed to $250^{\circ} \mathrm{C} ; 5=$ Scapula exposed to $300^{\circ} \mathrm{C} ; 6=$ Fibula burnt to ashes. 


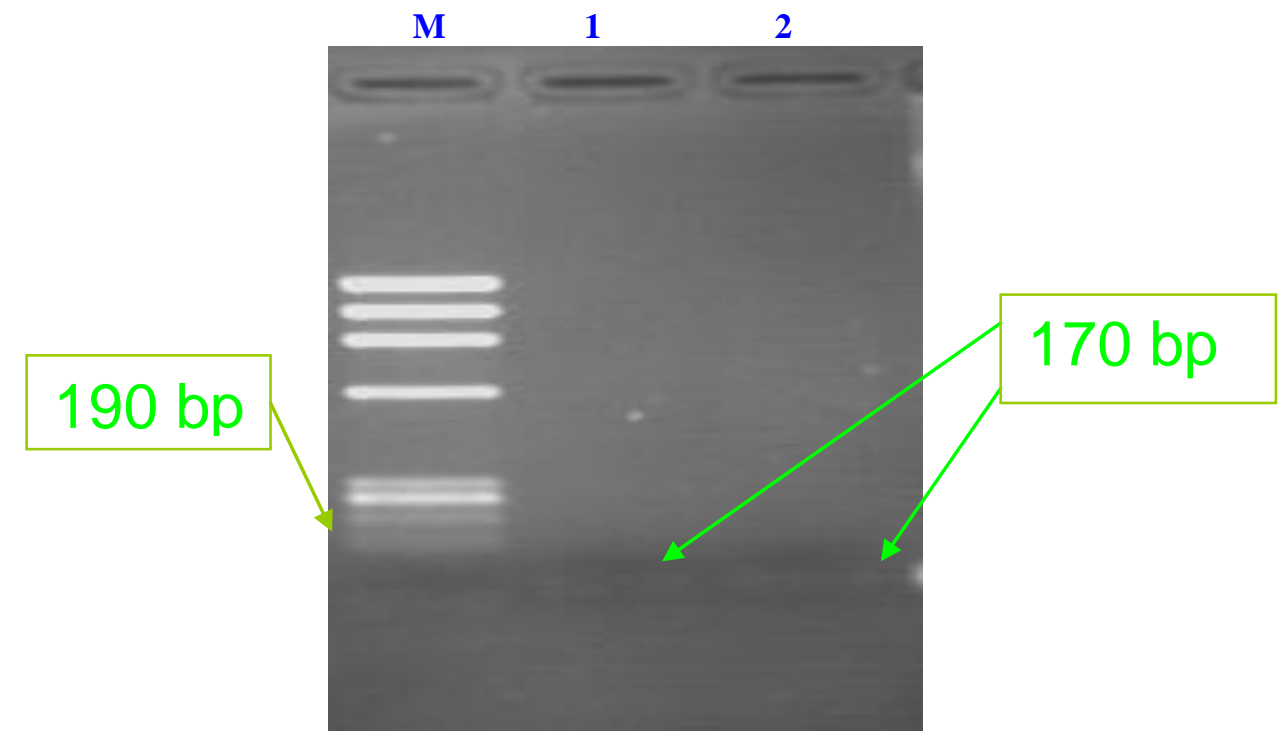

Figure 2b: Amplification of the alphoid repeats Y-specific primers from the DNA of the bone samples exposed to various degrees of heat for 20 minutes, electrophoretically separated on 1.5\% agarose gel (Reassay: 005/14).

Lanes: $\mathrm{M}=1000 \mathrm{bp}$ DNA ladder (Lot: 73020G3. Toyobo); $1=$ Little finger exposed to $100^{\circ} \mathrm{C} ; 2=\mathrm{Hip}$ bone exposed to $150^{\circ} \mathrm{C}$.

Table 3 compares the PCR amplification for bone samples exposed to various degrees of temperatures between amelogenin gene and alphoid repeats primers. With both amelogenin gene and alphoid repeats, amplification of $\mathrm{X}$ chromosome was achieved in samples 1 and 2. Amplification of X chromosome in sample 6 was negative with both amelogenin gene and alphoid repeats. In the remaining samples (3-5), X chromosome was positive with alphoid repeats, but negative with amelogenin gene. Amplification of Y chromosome was achieved in all the samples, with amelogenin gene, but achieved in only samples 1 and 2, with alphoid repeats. PCR reaction for the amplification of $\mathrm{Y}$ chromosome with alphoid repeats was not done for samples 3-6. No amplification was achieved for either $\mathrm{X}$ or $\mathrm{Y}$ chromosomes with amelogenin, and for $\mathrm{X}$ chromosome with alphoid repeats in sample 6. The genetic sex of sample 6 was therefore, not identified with either amelogenin gene or alphoid repeats. Correct genetic sex identification was achieved in samples 2 with both amelogenin gene and alphoid repeats. Genetic sexes of samples 4 and 5 were accurately identified with alphoid repeats, but wrongly identified with amelogenin gene. Genetic sex of sample 1 was wrongly identified with both amelogenin and alphoid repeats.

Table 3: Result of Comparison of PCR amplification for Bone Samples Exposed to Various Degrees of Temperatures between Amelogenin Gene and Alphoid Repeats.

\begin{tabular}{|c|c|c|c|c|c|c|c|c|c|}
\hline \multirow[t]{2}{*}{ SN } & \multirow[b]{2}{*}{$\begin{array}{l}\text { Deg- } \\
\text { rees to } \\
\text { which } \\
\text { bone } \\
\text { was } \\
\text { heated }\end{array}$} & \multirow{2}{*}{$\begin{array}{l}\text { Bone } \\
\text { sampled }\end{array}$} & \multirow{2}{*}{$\begin{array}{l}\text { Morpho- } \\
\text { logical } \\
\text { sex }\end{array}$} & \multicolumn{3}{|c|}{ Amelogenin gene } & \multicolumn{3}{|c|}{ Alphoid repeats } \\
\hline & & & & $\begin{array}{l}\mathrm{X} \\
\text { Chromo- } \\
\text { some } \\
\text { amplifica- } \\
\text { tion } \\
(330 \mathrm{bp})\end{array}$ & $\begin{array}{l}\text { Y } \\
\text { Chromo- } \\
\text { some } \\
\text { amplifica- } \\
\text { tion } \\
(218 \mathrm{bp})\end{array}$ & Genetic sex & $\begin{array}{l}\text { X chromo- } \\
\text { some } \\
\text { amplificati } \\
\text { on } \\
(130 \mathrm{bp})\end{array}$ & $\begin{array}{l}\text { Y } \\
\text { chromo- } \\
\text { some } \\
\text { amplifi- } \\
\text { cation } \\
(170 \mathrm{bp})\end{array}$ & $\begin{array}{l}\text { Gene- } \\
\text { tic sex }\end{array}$ \\
\hline 1 & $100^{\circ} \mathrm{C}$ & $\begin{array}{l}\text { Little } \\
\text { finger }\end{array}$ & Female & Positive & positive & Male & Positive & positive & Male \\
\hline 2 & $150^{\circ} \mathrm{C}$ & Hip bone & Male & Positive & positive & Male & Positive & positive & Male \\
\hline 3 & $200^{\circ} \mathrm{C}$ & Femur & Male & Negative & positive & Male & Positive & Not done & Female \\
\hline 4 & $250^{\circ} \mathrm{C}$ & Rib & Female & Negative & positive & Male & Positive & Not done & Female \\
\hline 5 & $300^{\circ} \mathrm{C}$ & Scapula & Female & Negative & positive & Male & Positive & Not done & Female \\
\hline 6 & Ashes & Fibula & Female & Negative & Negative & $\begin{array}{l}\text { Uniden- } \\
\text { Tified }\end{array}$ & Negative & Not done & $\begin{array}{l}\text { Uniden- } \\
\text { tified }\end{array}$ \\
\hline
\end{tabular}

$\mathrm{SN}=$ Serial Number.

Correct genetic sex identification was achieved in samples 2 only, with both amelogenin gene and alphoid repeats. Genetic sexes of samples 4 and 5 were accurately identified with alphoid repeats, but wrongly identified with amelogenin gene. Genetic sex of sample 1 was wrongly identified with both amelogenin and alphoid repeats. The genetic sex of sample 6 was not identified with either amelogenin gene or alphoid repeats. 


\section{Discussion}

Currently, the determination of human gender in forensic laboratories, is mainly based on methods developed to analyze DNA samples. Although these DNA-based existing technologies could provide high classification accuracy, these methods are tedious, expensive, and time consuming (especially for extracting the DNA from forensic samples) [20]. In this study, powdered cadaveric skeletal fragments were exposed to various degrees of temperatures. The duration of heating of each sample at the required temperature, was for 20 minutes. That was after having preheated the furnace incinerator to the respective required temperatures for the respective samples. However, heating of sample 6 was not regulated to any limit of temperature and time. Thus, the aim was to heat the sample until the physical appearance of the sample changed to ashes.

With amelogenin gene, amplification for $\mathrm{Y}$ chromosome was achieved in all the samples, except in sample 6, which showed negative. Amplification for X chromosome was achieved in samples 1 and 2 only. Accurate genetic sex identification was achieved in samples 2 and 3 only. Genetic sexes of samples 1, 4 and 5 were wrongly identified. No genetic sex identification was achieved for sample burnt to ashes (sample 6). The genetic sex identification of samples 1 and 2 was based on the amplification of both $\mathrm{X}$ and $\mathrm{Y}$ chromosomes. However, the genetic sex of sample 1 was wrongly identified. Thus, it was genetically identified as male while its morphological gender was female. Sample 2 was correctly identified as male, genetically. The accurate identification of sample 3 was as a result of amplification of only the Y chromosome of the sample. Samples 4 and 5 were wrongly identified as males genetically, instead of females. This was because of failure of amplification of the $\mathrm{X}$ chromosome and amplification of the $\mathrm{Y}$ chromosome of the samples.

The wrong genetic sex identification observed in samples 1,4 and 5 could be as a result of contamination while handling/processing the samples. Genetic sex identification of sample 6 could not be achieved for the fact that none of the chromosomes (X and/or Y) amplified. In this study, this indicates that DNA in this sample was destroyed and could not amplify. This might mean that in real forensic situations, genetic sex identification of human body burnt to ashes could not be determined. A similar study by von Wurmb-Schwark et al., 2004 [7], showed that they could not amplify DNA from ten cadavers with STR typing and amelogenin gene specific gender determination method. They concluded that STR typing of cremation remains was to be considered unreliable and not suitable for forensic purposes.

A preferential amplification of Y chromosome was noticed in this study. This was similarly reported by Faerman et al., 1995 [4] and Matheson and Loy, 2001[17]. The higher sensitivity of detection of the Y chromosome might be due to the shorter amplification product or to the nature of the allele-specific primers. Regardless of the reason, this suggests that this method (sex identification with amelogenin gene) is more prone to miss a female specimen than a male. On the other hand, the more efficient amplification of the $\mathrm{Y}$ allele suggests that presence of a single $330 \mathrm{bp}$ product indicates a female [4].

The success rate for gender identification with amelogenin gene in this study showed that $33.3 \%$ accurate genetic sex identification was achieved. This is favourably comparable with reports by earlier workers who conducted similar studies on ancient bone fragments with amelogenin gene. In 1995, Faerman et al. [4], reported 41\% success rate, Faerman et al., 1998[21] reported 44\% success, Mays and Faerman, 2001[22] reported $42 \%$ and Matheson and Loy, 2001[17] reported $40 \%$.

PCR sex determination of human bone fragments exposed to various degrees of temperatures for 20 minutes, with alphoid repeats primers showed that amplification was achieved for $\mathrm{X}$ chromosome in all the samples, except sample 6 (negative). Amplification for Y chromosome was achieved in samples 1 and 2 only.

Correct genetic sex identification was achieved in samples 2, 4 and 5, yielding a success rate of $50 \%$. Genetic sex of samples 1 and 3 were wrongly identified. Sample 1 was wrongly identified as a male, instead of a female, while sample 3 was wrongly identified as a female, instead of a male.

The genetic sex identification of samples 1 and 2 was based on the amplification of both $\mathrm{X}$ and $\mathrm{Y}$ chromosomes. However, the genetic sex of sample 1 was wrongly identified as stated earlier. Sample 2 was correctly identified genetically as male. Thus, its genetic sex confirmed its morphological sex.

PCR reaction of Y chromosome for samples 3-6 was not done due to exhaustion of Y primers. However, PCR amplification of $\mathrm{X}$ chromosome was achieved in samples 3-5. Base on these results (amplification of only the $\mathrm{X}$ chromosome of these samples), the genetic sexes of these samples were, therefore, identified. Samples 4 and 5 were correctly identified as females. Thus, the genetic sexes of these samples correspond to their morphological sexes (females). However, the genetic sex of sample 3 did not tally with its morphological gender. Thus, the genetic sex of this sample was wrongly identified as female, instead of a male. However, it might be possible that this sample might have been accurately identified as male, if the Y primers were available to set PCR reaction for this sample.

Our findings have shown that DNA could be amplified with alphoid repeats after exposing a sample to temperature as high as $300^{\circ} \mathrm{C}$ for 20 minutes. No genetic sex identification was achieved for sample 6 . This was because no amplification was achieved for both $\mathrm{X}$ and $\mathrm{Y}$ chromosomes. It could be that the DNA in this sample was completely destroyed by heat to which it was exposed, or the DNA was severely degraded by the heat, to 
such an extent that it was not amplifiable. As well, there could be PCR inhibitors that could inhibit the PCR process of the sample.

In general, preferential amplification of $\mathrm{X}$ chromosome was noticed with alphoid repeats. This could be a demonstration of the damaged state of the DNA of the samples as earlier reported by Matheson and Loy, 2001 [17]. Regardless of the reason, this suggests that sex identification with alphoid repeats has a high tendency of missing a male specimen than a female. Thus, the amplification of $\mathrm{X}$ alphoid repeats primerdefined length of $130 \mathrm{bp}$ was possible, but the longer Y alphoid repeats primer-defined length $170 \mathrm{bp}$ might not have been available for amplification.

It should be stressed, however, that in real fire situations, direct exposure of the skeleton to the high temperatures of the fire is often prevented by the protective soft tissues. The potential difference in thermal effects between bones subjected to a controlled burn to those in realistic fire situations, where the temperatures and the duration of those fluctuate, further highlights the inappropriateness of direct extrapolation of experimental results to real life situations. The use of isolated bones in temperature-related experiments is, therefore, not meaningful because the relationship between temperatures used experimentally and those experienced by bones/teeth in situ in real fire situations cannot be ascertained. The data generated from studies utilizing isolated human bones cannot realistically contribute to human identification in fire-related forensic casework, or to the determination of fire temperatures based on the condition of those bones.

Comparison of PCR results for the samples exposed to various degrees of heat, between amelogenin gene and alphoid repeats (Table 3), showed that amplification of X chromosome was achieved in samples 1-5, with alphoid repeats. With amelogenin gene, amplification of $\mathrm{X}$ chromosome was achieved in samples 1 and 2 only. For samples 3-6, amplification for X chromosome was negative with amelogenin gene. Amplification of $\mathrm{Y}$ chromosome was achieved in samples 1 and 2 only with alphoid repeats, while with amelogenin gene, $\mathrm{Y}$ chromosome amplified in samples 1-5. No amplification was achieved for either $\mathrm{X}$ or $\mathrm{Y}$ chromosomes with both amelogenin and alphoid repeats in sample 6 (burnt to ashes). The genetic sex of this sample was therefore, not identified by either amelogenin gene or alphoid repeats primers. The genetic sex of sample 2 was accurately identified by both amelogenin gene and alphoid repeats, as male. This was based on the amplification of both $\mathrm{X}$ and $\mathrm{Y}$ chromosomes of the respective primers. Although, $\mathrm{X}$ and $\mathrm{Y}$ chromosomes of sample 1 amplified with both amelogenin gene and alphoid repeats (revealing the genetic sex of the sample to be male), neither of these primers (amelogenin and/or alphoid repeats) gave accurate genetic sex of this sample, as its morphological sex was female. Sample 3 was accurately genetically identified as male by amelogenin gene, base on the amplification of only the $\mathrm{Y}$ chromosome of the sample. With alphoid repeats, only the $\mathrm{X}$ chromosome of the sample (sample 3) amplified. The PCR reaction with alphoid repeats primers for the Y chromosome of this sample was not done because the Y primers were exhausted. However, based on the available result, i.e., amplification of only the $\mathrm{X}$ chromosome of this sample with alphoid repeats, the sample was wrongly identified as female, instead of a male. It could be possible for this sample (sample 3) to have been accurately identified genetically as a male, if the Y primers were available for PCR reaction. The genetic sexes of samples 4 and 5 were wrongly identified as males, instead of females, with amelogenin gene. This is because of the successful amplification of only the $\mathrm{Y}$ chromosomes of the samples. Thus, the $\mathrm{X}$ chromosomes of these samples did not amplify with amelogenin gene. However, with alphoid repeats, the $\mathrm{X}$ chromosome of these samples (samples 4 and 5), gave successful amplification. Although the PCR reaction for Y chromosome with alphoid repeats was not done, the genetic sexes of these samples (4 and 5) were accurately identified as females, base on the available result. With amelogenin gene, a preferential amplification of Y chromosome was observed (samples 15). Contrastingly, with alphoid repeats, preferential amplification of $X$ chromosome was noticed (samples 1-5).

Generally, it was obvious that amplification was not achieved in sample 6 with both amelogenin and alphoid repeats. This meant that the DNA was not retrievable. This could be due to the degradation of the genetic material by multiple factors, as stated earlier.

\section{Conclusion}

This study has demonstrated the use of amelogenin gene and alphoid repeat in forensic study for genetic sex determination of burnt powdered skeletal fragments from Sokoto, Northwestern Nigeria, and that alphoid repeats yielded better results than amelogenin gene. This is the first known study determining the sex of burnt cadaveric skeletal fragments by means of PCR in Nigeria. There is need for further studies in Nigeria to complement the findings of this study.

\section{Acknowledgements}

We wish to thank the Education Trust Fund, Usmanu Danfodiyo University, Sokoto, Nigeria for the grant to undertake the bench work of this study at the Department of Medical Molecular Genetics, Division of Human Genetics and Genome Research, National Research Centre, Cairo, Egypt. 


\section{References}

[1]. J.A. Lorente, C. Entrada, C. Alvarez, B. Arce, B. Heinrchs, M. Lorente, et al., Identification of missing persons: the "Spanish Phoenix" Program Croatian Medical Journal. 42 (3) (2001) 267-70.

[2]. J.A.D. Melki, C.C.S. Martin, A.C. Simes, Procedimentos em exumacoes para investigacao de vinculo genetico em ossos, Rev Saude Publica. 35 (2001) 368-74

[3]. W. Harvey, Dental Identification and Forensic Odontology, London: Henry Kimpton Publishers, (1976) pp 36-37, 67-68.

[4]. M. Faerman, D. Filon, G. Kahila, C.L. Greenblatt, P. Smith, A. Oppenheim, Sex identification of archaeological human remains based on amplification of the X and Y amelogenin alleles. Gene, 167 (1995) 327-332.

[5]. B. Knight, Forensic Pathology, 1st Edition., London: Edward Arnorld, 3 (1991) pp 87-104.

[6]. A.C. Stone, G.R. Milner, S. Paabo, M. Stoneking, Sex Determination of ancient human skeletons using DNA, American Journal of Physical Anthropology, 99 (1996) 231-238.

[7]. N. von Wurmb-Schwark, E. Simeoni, A. Ringleb, M. Oehmichen, Genetic investigation of modern burned corpses, (2004) Assessed online $5^{\text {th }}$ May, 2010.

[8]. P.M. Mayne Correia, Fire modification of bone: a review of the literature. In: Haglund WD, Sorg MH, editors. Forensic taphonomy: the post-mortem fate of human remains. Boca Raton, FL: CRC Press, (1997) pp 275-86.

[9]. T.R. Schwartz, E. A. Schwartz, B.S. Mieszerski, L. McNally, L. Kobilinsky, Characterization of Deoxyribonucleic acid (DNA) obtained from teeth subjected to various environmental conditions. Journal of Forensic Science. 36 (1991) 979-990.

[10]. W.U. Spitz, Thermal injuries in: W.U. Spitz, editor. Medico legal investigation of death, 3rd edn. Springfield, IL: Charles C Thomas. 3, 1993.

[11]. B.A.J. Fisher, Techniques of crime scene investigation, 7th edn. Boca Raton, FL: CRC Press, 2004.

[12]. P. Nambiar, N. Jalil, B. Singh, The dental identification of victims of an aircraft accident in Malaysia, Int Dent J. 47 (1997) 9-15.

[13]. J. Dumancic, Z. Kaic, V. Njemirovskij, H. Brkic, D. Zecevic, Dental identification after two mass disasters in Croatia, Croatian Medical Journal, 42 (2001) 657-62.

[14]. A. Cooper, H.N. Poinar, Ancient DNA: Do it right or not at all, Science, 289 (2000) 1139.

[15]. A.K. Rees, J.M.Cox, Comparative Analysis of the Effects of Heat on the PCR-Amplification of Various Sized DNA Fragments Extracted from Sus Scrofa Molars, J. Forensic Sci. 55 (2) (2010) 410-417.

[16]. E. Cappelleni, B. Chiarelli, L. Sineo et al: Biomolecular study of the human remains from tomb 5859 in the Etruscan necropolis of Monterozzi, Tarquinia (Viterbo, Italy). Journal of Archaeological Science. 2004; 31: 603-612.

[17]. D.E. Matheson, T.H. Loy, Genetic Sex Identification of 9400-old Human skull Samples from Cayönü Tepesi,Turkey, Journal of Archaeological Science. 28 (2001) 569-575

[18]. M. Witt, R.P. Erickson, A rapid method for detection of Y-chromosomal DNA from dried blood specimens by the polymerase chain reaction, Hum Genet. 82, (1989) 271-274.

[19]. T. Maniatis, E. F. Fritchs, J. Sambrook, Molecular cloning: A Laboratory Manual. New York: Cold Spring Harbor Laboratory, (1982) pp 468

[20]. E. Widjaja, H.K. Lim, A. An, A novel method for human gender classification using Raman spectroscopy of fingernail clippings, The Analyst. DOI: 10.1039/b712389b (2008) 1-14.

[21]. M. Faerman, K G. Bar-Gal, D. Filon, C.L. Greenblatt, L. Stager, A. Oppenheim, P. Smith, Determining the Sex of Infanticide Victims from the Late Roman Era through Ancient DNA Analysis, Journal of Archaelogical Science, 25 (1998) $861-865$.

[22]. S. Mays, M. Faerman, Sex Identification in Some Putative Infanticide Victims from Roman Britain Using Ancient DNA, Journal of Archaeological Science, 28 (2001) 555-559. 